\title{
Nitrogen storage in density and size fractions varied with tillage practices and cropping systems under residue return
}

\author{
Yang Zhang ${ }^{1}$, Yan Zhang ${ }^{1}$, Yan Gao $^{1}$, Dandan Huang ${ }^{1}$, Xuewen Chen ${ }^{1}$, Shixiu Zhang ${ }^{1}$, \\ Xiaoping Zhang ${ }^{1}$, Neil McLaughlin ${ }^{2}$, Yang Xiang ${ }^{3}$, and Aizhen Liang ${ }^{1}$ \\ ${ }^{1}$ Northeast Institute of Geography and Agroecology Chinese Academy of Sciences \\ ${ }^{2}$ Ottawa Research and Development Centre \\ ${ }^{3}$ Jilin Agricultural Technology Extension Station
}

January 3, 2022

\begin{abstract}
Residue return can prevent or restore the degradation of cropland, meanwhile, additional N input from residue return inevitably result in the changes of soil nitrogen $(\mathrm{N})$ pools. Our objectives were to evaluate these changes in a 16-year field experiment. The residue return experiment consisted of no-tillage (NT) and mouldboard plough (MP), combined with continuous maize (Zea mays L.) (MM) and maize-soybean (Glycine max Merr.) rotation (MS) cropping systems, that is, NTMM, NTMS, MPMM, MPMS; conventional tillage (removal of crop residue and deep plough) with continuous maize (CTMM) was included as a control. The soil was separated into density ( $\mathrm{LF}$, light fraction) and particle size (sand, silt and clay) fraction. In 0-5 $\mathrm{cm}$ and 5-10 cm layers, soil TN content in NT was higher than MP, whereas the opposite trend was observed in 10-20 cm. Thus, the stratification ratio of soil TN was greater under NT. Cropping system affected soil TN as MM > MS. Residue return increased soil N storage by $6.44 \%-24.85 \%$ in the plough layer. Taking CTMM as the baseline, NTMM and MPMM increased the N storage in all physical fractions, while the decrease of silt-N storage was observed in NTMS and MPMS. Under residue return, the distribution of $\mathrm{N}$ storage changes in LF and sand fraction was affected by tillage practice, and that in silt and clay fraction was affected by cropping system. In summary, NTMM is effective for soil N accumulation due to its highest $\mathrm{N}$ storage and all physical fractions of $\mathrm{N}$ storage was enhanced.
\end{abstract}

Nitrogen storage in density and size fractions varied with tillage practices and cropping systems under residue return

Yang Zhang ${ }^{\mathrm{a}, \mathrm{b}}$, Yan Zhang ${ }^{\mathrm{a}}$, Yan Gao ${ }^{\mathrm{a}, \mathrm{b}}$, Dandan Huang ${ }^{\mathrm{a}}$, Xuewen Chen $^{\mathrm{a}}$, Shixiu Zhang ${ }^{\mathrm{a}}$, Xiaoping Zhang ${ }^{\mathrm{a}}$, Neil McLaughlin ${ }^{\mathrm{c}}$, Yang Xiang ${ }^{\mathrm{d}}$, Aizhen Liang ${ }^{\mathrm{a}, \mathrm{b}^{*}}$

${ }^{a}$ Northeast Institute of Geography and Agroecology, Chinese Academy of Sciences, Changchun 130102, China, ${ }^{\mathrm{b}}$ University of Chinese Academy of Science, Beijing 100864, China, ${ }^{\mathrm{c}}$ Ottawa Research and Development Centre, Central Experimental Farm, Agriculture and Agri-Food Canada, Ottawa, Ontario, ON K1A 0C6, Canada, d

JiLin Agricultural Technology Extension Station, Changchun 130021, China

*Corresponding author: Aizhen Liang

Address: Northeast Institute of Geography and Agroecology, CAS, 4888 Shengbei Street, Changchun 130102, China

Tel: (+86)0431-85542349

E-mail address: liangaizhen@iga.ac.cn 


\begin{abstract}
Residue return can prevent or restore the degradation of cropland, meanwhile, additional N input from residue return inevitably result in the changes of soil nitrogen $(\mathrm{N})$ pools. Our objectives were to evaluate these changes in a 16-year field experiment. The residue return experiment consisted of no-tillage (NT) and mouldboard plough (MP), combined with continuous maize (Zeamays L.) (MM) and maize-soybean (Glycine max Merr.) rotation (MS) cropping systems, that is, NTMM, NTMS, MPMM, MPMS; conventional tillage (removal of crop residue and deep plough) with continuous maize (CTMM) was included as a control. The soil was separated into density (LF, light fraction) and particle size (sand, silt and clay) fraction. In 0-5 cm and 5-10 cm layers, soil TN content in NT was higher than MP, whereas the opposite trend was observed in 10-20 cm. Thus, the stratification ratio of soil TN was greater under NT. Cropping system affected soil TN as MM > MS. Residue return increased soil N storage by $6.44 \%-24.85 \%$ in the plough layer. Taking CTMM as the baseline, NTMM and MPMM increased the $\mathrm{N}$ storage in all physical fractions, while the decrease of silt-N storage was observed in NTMS and MPMS. Under residue return, the distribution of N storage changes in LF and sand fraction was affected by tillage practice, and that in silt and clay fraction was affected by cropping system. In summary, NTMM is effective for soil N accumulation due to its highest $\mathrm{N}$ storage and all physical fractions of $\mathrm{N}$ storage was enhanced.
\end{abstract}

Keywords: residue return; nitrogen storage; physical fractions

\title{
1. Introduction
}

Crop residue return can prevent or restore the degradation of cropland (Zhang et al., 2019), it has been recommended as an eco-friendly practice for increasing soil fertility, enhancing crop production and saving labor (Bailey and Lazarovits, 2003; Wang et al., 2015; Zhang et al., 2018). What's more, returning crop residue could promote soil $\mathrm{N}$ pool by $10.7 \%$ (Wang et al., 2018). It is well documented that crop residue return, especially combined with no-tillage (NT) increases the soil N storage significantly (Chen et al., 2009; Ramnarine et al., 2015; Varvel and Wilhelm, 2011). In additional, soil N storage was also varied with the types of returned crop residue due to its difference in quantity and quality (Jagadamma et al., 2007; Congreves et al., 2016).

Nitrogen $(\mathrm{N})$ plays an important role in determining plant growth and often a limited nutrient in terrestrial ecosystems (Fowler et al., 2013). Excessive N input from fertilizer has been applied to improve crop yields owing to the demand by the growing global human population (Galloway, 2003; Vitousek et al., 2009). Meanwhile, $\mathrm{N}$ losses from agriculture is a major threat to the ecological environment, human health and economic development (Bowles et al., 2018). Soil total nitrogen (TN) content is a valuable indicator for soil fertility and its storage can reflect the net balance between $\mathrm{N}$ inputs and outputs (Cassman et al., 2002). Combining the physical density and size fractionation method helps to understand the component and characteristic the soil N pools (Diochon et al., 2016), which has been widely applied in studies of soil organic carbon (SOC) (Cyle et al., 2016). The different properties of N physical fractions are important for soil fertility, crop growth and $\mathrm{N}$ loss. Numerous researchers have already studied how residue return affect soil $\mathrm{N}$ storage, whereas studies on $\mathrm{N}$ storage changes in physical fractions are rare.

In this study, soil physical fractionation method was used to determine $\mathrm{N}$ concentrations in bulk soil (TN), LF (LF-N), sand (sand-N), silt (silt-N) and clay (clay-N) fractions under contrasting tillage practices with two different cropping systems in a long-term residue return field experiment in black soil. Our objectives were: 1) to quantification the soil $\mathrm{N}$ storage in the plough layer under residue return; 2) to evaluate the changes of $\mathrm{N}$ storage in physical fractions under different tillage practices and cropping systems with residue return.

\section{Materials and methods}

\subsection{Experimental site}

The long-term field experiment was initiated in fall 2001, and was located at the Experimental Station $\left(44^{\circ} 12^{\prime} \mathrm{N}, 125 \mathrm{deg} 33^{\prime} \mathrm{E}\right)$ of the Northeast Institute of Geography and Agroecology, Chinese Academy of Sciences, in Dehui County, Jilin Province, China. This site is in the North Temperate Zone and belongs to a 
continental monsoon climate with 4.4 mean annual temperature and $520 \mathrm{~mm}$ mean annual precipitation. More than $70 \%$ of the annual precipitation occurs during the plant growing season from June to August. Soil is classified as Typic Hapludoll (USDA Soil Taxonomy) with a clay loam texture ( $36 \%$ clay, $24.5 \%$ silt and $39.5 \%$ sand). Continuous maize and intensive deep tillage were the prevalent agriculture management in this region and had been applied for more than 15 years continuously prior to initiation of the field experiment. Soil properties were given by Liang et al., (2007).

\subsection{Field experimental design}

The long-term experiment was a split-plot randomized block design with four replications. Tillage including no-tillage (NT) and mouldboard plough (MP) was applied at the whole plot level (10.5 $\mathrm{m} \mathrm{x} 20 \mathrm{~m})$. Cropping system was set as the sub-plot $(5.2 \mathrm{~m} \times 20 \mathrm{~m})$ treatment and included continuous maize (MM) and 2-year maize soybean rotation (MS). Therefore, this study in involves four residue return treatments: no-tillage with maize-soybean (NTMS) or continuous maize (NTMM); mouldboard plough with maize-soybean (MPMS) or continuous maize (MPMM); and the control: conventional tillage with continuous maize without residue return (CTMM), this is the traditional management system in the region. The average annual amount of residues returned to the field was $2.6 \mathrm{Mg} \mathrm{ha}^{-1}$ for soybean and $11 \mathrm{Mg} \mathrm{ha}^{-1}$ for maize. In the NTMS and NTMM plots, the only soil disturbance was by a no-tillage planter (KINZE-3000, Williamsburg, IA, USA). The other three treatments (MPMS, MPMM and CTMM) had ridge building in June and mouldboard plough ([?] $20 \mathrm{~cm}$ ) after harvest. The only difference between CTMM and MPMM is whether or not residues were returned.

The amount of fertilizer applied was different for maize and soybean. For maize, $\mathrm{N}, \mathrm{P}_{2} \mathrm{O}_{5}$ and $\mathrm{K}_{2} \mathrm{O}$ fertilizers were applied at $100,45.5$ and $78 \mathrm{~kg} \mathrm{ha}^{-1}$, respectively, as starter fertilizers. At the maize $\mathrm{V} 6$ growth stage (six maize leaves with collars), an additional $50 \mathrm{~kg} \mathrm{~N}^{-1}$ was applied as top dressing. For the soybean, only starter fertilizer was applied, $\mathrm{N}, \mathrm{P}_{2} \mathrm{O}_{5}$ and $\mathrm{K}_{2} \mathrm{O}$ fertilizers were 40,60 and $80 \mathrm{~kg}$ ha ${ }^{-1}$, respectively. Starter fertilizers were applied with the side-banding attachment on the no-tillage planter.

\subsection{Soil sampling and measurements}

Seven soil core samples were collected from each plot in MM and the maize phase of the MS rotation using a $2.64 \mathrm{~cm}$ diameter hand auger before seeding in 2017. Soil cores were separated into three segments, 0-5 $\mathrm{cm}, 5-10 \mathrm{~cm}$ and $10-20 \mathrm{~cm}$, and all cores for each depth segment of the same plot were thoroughly mixed to form a composite sample for the respective depth. Stubble and stones were removed, and air-dried soil was sieved to pass a $2 \mathrm{~mm}$ sieve and stored in glass bottles for future analysis. The soil bulk density (BD) was measured using the cutting ring method, the soil samples were oven-dried at $105 \operatorname{deg} \mathrm{C}$ to a constant weight to calculate water content and subsequently calculate soil BD.

The soil physical fractionation followed a protocol described by Diochon et al., (2016). First, NaI solution $\left(1.7 \mathrm{~g} \mathrm{~cm}^{-3}\right)$ was used to separate two density fractions: $<1.7 \mathrm{~g} \mathrm{~cm}^{-3}$ (light fraction, LF) and $>1.7 \mathrm{~g} \mathrm{~cm}^{-3}$ (heavy fraction, HF). Then HF samples were separated into three size fractions: $>53 \mu \mathrm{m}$ (sand), $5-53 \mu \mathrm{m}$ (silt) and $<5 \mu \mathrm{m}$ (clay), by wet sieving method (Magid and Kjærgaard, 2001) and Stokes's law (Kroetsch and Wang, 2006). After separation, all the physical fractions were dried at 60 in an oven to a constant weight. The concentration of $\mathrm{N}$ in bulk soil (TN) and four physical fractions (LF-N, sand-N, silt-N, clay-N) was measured with an Elementar Vario EL Cube (Elementar Analysis system GmbH, Hanau, Germany).

\subsection{Data analysis}

Soil $\mathrm{N}$ storage $\left(\mathrm{Mg} \mathrm{N} \mathrm{ha}^{-1}\right)$ was calculated on the basis of equivalent soil mass according to the procedure of Ellert and Bettany (1995).

The stratification ratio (SR) of soil TN was calculated by:

$\mathrm{SR}=\mathrm{TN}_{0-5} / \mathrm{TN}_{10-20}(1)$

where $\mathrm{TN}_{0-5}$ and $\mathrm{TN}_{10-20}$ are the soil $\mathrm{TN}$ contents $\left(\mathrm{g} \mathrm{N} \mathrm{kg}^{-1}\right.$ soil) in the 0-5 $\mathrm{cm}$ layer and 10-20 cm layer, respectively. 
The changes of $\mathrm{N}$ storage ([?]N storage, $\left.\mathrm{kg} \mathrm{N} \mathrm{ha}^{-1} \mathrm{yr}^{-1}\right)$ in residue return treatments was calculated as:

[?] $\mathrm{N}$ storage $=\left(\mathrm{N}_{\mathrm{r}}\right.$ storage- $\mathrm{N}_{\mathrm{CTMM}}$ storage $) \times 1000(2)$

where $\mathrm{N}_{\mathrm{r}}$ storage represents the $\mathrm{N}$ storage $\left(\mathrm{Mg} \mathrm{N}^{-1}\right)$ in treatments with residue return (NTMS, NTMM,

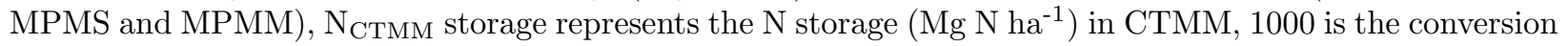
from $\mathrm{Mg}$ to $\mathrm{kg}$.

The storage of $\mathrm{N}$ in physical fractions ( $\mathrm{F}-\mathrm{N}$ storage, $\mathrm{kg} \mathrm{N}$ ha ${ }^{-1}$ ) was calculated by:

$\mathrm{F}-\mathrm{N}$ storage $=\left(\mathrm{F}-\mathrm{N}_{\text {percentage }} / 100\right) \times$ soil $\mathrm{N}$ storage $\mathrm{x} 1000(3)$

where $\mathrm{F}-\mathrm{N}_{\text {percentage }}$ is the percentage of $\mathrm{N}$ in each fraction (\%), 1000 is the conversion from $\mathrm{Mg}$ to $\mathrm{kg}$.

Two-way ANOVA analysis was used to examine the effects of tillage practice and cropping system on soil TN content and the SR of TN. We conducted variance partitioning analysis to assess the relative contribution of tillage practice and cropping system to the change of $\mathrm{N}$ storage in physical fractions (F-[?] $\mathrm{N}$ storage) and its relatively distribution (\%). All the statistical analyses were carried out with SPSS 16.0 (SPSS Inc., Chicago, Illinois, USA) and the R software (version 3.6.2).

\section{Results}

\subsection{Soil TN content and its stratification ratio, and $N$ content in physical fractions}

Soil TN was significantly $(P<0.01)$ affected by tillage practice $(\mathrm{T})$ and cropping systems $(\mathrm{CS})$ in three layers. In the surface 0-5 cm (Figure 1, a) and 5-10 cm layers (Figure 1, b), the content of soil TN under NT treatments was higher than MP treatments and CTMM under the same cropping system; in 10-20 cm layer (Figure 1, c), the content of soil TN under MP was higher $(P<0.01)$. The effect of cropping system on soil TN was consistent in three soil layers (Figure 1, a-c) with MM $>$ MS $(P<0.01)$. Additionally, the content of TN at $5-10 \mathrm{~cm}$ soil layer (Figure $1, \mathrm{~b})$ was also $(P<0.01)$ affected by the interaction of tillage practice and cropping system (TxCS). The stratification ratio (SR) of soil TN was significantly $(P<0.001)$ affected by tillage practice (T) (Figure 2), and it was much higher in NT treatments (1.70 on average) than in MP treatments (1.13 on average) and CTMM (1.14).

The effects of tillage practice (T), cropping system (CS) and their interaction (TxCS) on the $\mathrm{N}$ contents in physical fractions ( $\mathrm{F}-\mathrm{N}$ content) and the percentage of $\mathrm{N}$ in each fraction $\left(\mathrm{F}-\mathrm{N}_{\text {percentage }}\right)$ are shown in Table 1. In the $0-5 \mathrm{~cm}$ layer, tillage significantly $(P<0.001)$ affected the $\mathrm{F}-\mathrm{N}$ contents and the $\mathrm{F}-\mathrm{N}_{\text {percentage }}$ except silt- $\mathrm{N}_{\text {percentage }}$ (Table 1). Under the same cropping system, the F-N contents in treatments with NT were significantly $(P<0.001)$ higher than with MP. The LF-N content of NT treatments was 5.2 times (MS) and 3.8 times (MM) higher than MP treatments. The LF- $\mathrm{N}_{\text {percentage }}$ and sand- $\mathrm{N}_{\text {percentage }}$ in NT treatments were also higher. In addition, the silt- $\mathrm{N}$ content and silt- $\mathrm{N}_{\text {percentage }}$ were affected by cropping system $(P$ $<0.001)$ and TxCS interaction $(P<0.001)$, the silt-N content was greater in treatments with MM than with MS, and was the highest in NTMM. However, the clay- $\mathrm{N}_{\text {percentage }}$ in NT treatments was lower than MP treatments even though clay-N content in NT treatments was higher. In the 5-10 cm layer, the F-N contents in all fractions except clay were significantly $(P<0.05)$ affected by cropping system with MM $>$ MS (Table 1). Compared with MS, the LF-N content and silt-N content in treatments with MM were $76.9 \%$ and $83.3 \%$ higher in NT, $15.4 \%$ and $26.3 \%$ higher in MP, respectively. The LF-N content and sand-N content were also significantly affected by tillage practice $(P<0.05)$ and TxCS interaction $(P<0.05)$. Except for the clay- $\mathrm{N}_{\text {percentage }}$, the F-N content and F-N $\mathrm{N}_{\text {percentage }}$ of all fractions in NTMM treatment was the highest among all treatments. In the 10-20 cm layer, the F-N content in all fractions except sand-N were significantly $(\mathrm{P}<0.001)$ influenced by tillage practice, cropping system and TxCS interaction (Table

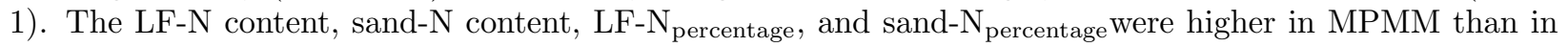
the other treatments. The clay-N content in four residue return treatments was higher than CTMM.

\subsection{Soil $N$ storage in bulk soil and correlation parameters}

After 16-year agriculture management, soil N storage of residue return treatments was significantly $(P<$ 
0.05) increased compared with CTMM in 0-20 cm depth (Table 2), and the descending sequence of soil $\mathrm{N}$ storage was NTMM (4.46 Mg N ha $\left.{ }^{-1}\right)>\operatorname{MPMM}\left(4.10 \mathrm{Mg} \mathrm{N} \mathrm{ha}^{-1}\right)>\operatorname{NTMS}\left(3.92 \mathrm{Mg} \mathrm{N} \mathrm{ha}{ }^{-1}\right)$ [?] MPMS $\left(3.80 \mathrm{Mg} \mathrm{N} \mathrm{ha}{ }^{-1}\right)>$ CTMM $\left(3.57 \mathrm{Mg} \mathrm{N} \mathrm{ha}^{-1}\right)$. The increment of [?]N storage in NTMM was the highest with $887.03 \mathrm{~kg} \mathrm{~N} \mathrm{ha}^{-1}$. The annual $\mathrm{N}$ input of residue $\left(\mathrm{N}_{\mathrm{a}-\text { residue }}\right)$ in $\mathrm{MM}$ treatments $\left(83.6 \mathrm{~kg} \mathrm{~N} \mathrm{ha}^{-1} \mathrm{yr}^{-1}\right.$ on average) was higher than MS (62.6 kg N ha-1 $\mathrm{yr}^{-1}$ on average including both maize and soybean phases), whereas CTMM was the lowest $\left(27.4 \mathrm{~kg} \mathrm{~N} \mathrm{ha}^{-1} \mathrm{yr}^{-1}\right)$. Soil $\mathrm{N}$ storage was positively related to the annual $\mathrm{N}$ input of residue (Figure 3). The maize yield in MS treatments (10.64 $\mathrm{Mg} \mathrm{ha}^{-1}$ on average) was higher than MM (9.31 Mg ha ${ }^{-1}$ on average), and they were both significantly higher than CTMM with $8.94 \mathrm{Mg} \mathrm{ha}^{-1}$. There was no difference in soybean yield between NTMS and MPMS.

\section{$3.3 N$ storage change in physical fractions of residue return treatments}

Taking CTMM as the baseline, the change of the $\mathrm{N}$ storage in physical fractions (F-[?]N storage) varied among residue return treatments (Figure 4, a). Considering the variable of soil $\mathrm{N}$ storage changes in residue return treatments (Table 2), the distribution of F-[?]N storage (\%) was calculated for each treatment (Figure 4, b). Treatments with MM enhanced the F-[?]N storage in all fractions, while the decline of silt-[?]N storage under treatments with MS was observed. The LF- and sand-[?]N storage were both the highest in NTMM than other treatments, while the distribution of LF-[?]N storage in NTMS was the highest. The reduction of silt-[?]N storage in NTMS (-206.2 $\left.\mathrm{kg} \mathrm{N} \mathrm{ha}^{-1}\right)$ was greater than MPMS (-59.9 $\left.\mathrm{kg} \mathrm{N} \mathrm{ha}^{-1}\right)$, and the increase of silt-[?]N storage in NTMM $\left(204.2 \mathrm{~kg} \mathrm{~N} \mathrm{ha}{ }^{-1}\right)$ was greater than MPMM $\left(67.9 \mathrm{~kg} \mathrm{~N} \mathrm{ha}^{-1}\right)$. The distribution of silt-[?]N storage (\%) in treatments showed the same trend with silt-[?]N storage. The accumulation of clay-[?]N storage was the highest among all physical fractions, and ranged from $318.4 \mathrm{~kg} \mathrm{~N}^{-1}$ to $448.5 \mathrm{~kg}$ $\mathrm{N}$ ha ${ }^{-1}$. The clay-[?]N storage was significantly $(P<0.05)$ higher in NT treatments than MP treatments, whereas the distribution of clay-[?]N storage varied with cropping systems (MS $>M M)$.

The variation partitioning demonstrated that tillage practice ( $\mathrm{T}$ ) and cropping system (CS) accounted for $74.8 \%-99.2 \%$ of the variation in $\mathrm{N}$ storage change in physical fractions (F-[?]N storage) (Figure 5 , a-d). The LF-, sand- and clay-[?] $\mathrm{N}$ storage were mainly determined by tillage practice, which explained respectively $77.8 \%, 57.8 \%$ and $90.8 \%$ of the variation; the silt-[?]N storage was mainly determined by cropping system $(81.8 \%)$. However, the distributions of LF- and sand-[?]N storage were influenced by tillage practice (Figure 5, e-f), $65.1 \%$ (LF) and $95.0 \%$ (sand) of the variation was explained, whereas the distributions of silt- and clay-[?]N storage were influenced by cropping system, $90.4 \%$ (silt) and $99.3 \%$ (clay) of the variation was explained (Figure 5, g-h).

\section{Discussion}

\subsection{Effects of tillage practice and cropping system on soil TN content and its storage under residue return}

Our research showed that tillage practice had significant impact on soil TN in the plough layer $(0-20 \mathrm{~cm})$, and the impact varied with soil layers (Figure 1). In the 0-5 cm and 5-10 cm layer, soil TN content was higher in NT than MP, whereas the reverse trend was observed in 10-20 cm layer. The results were consistent with researches in other regions (Angers et al., 1997; Spargo et al., 2008). Franzluebbers (2002) introduced the concept of soil stratification ratio (SR) of SOM pools as an indicator to evaluate soil quality, and emphasized that high SR was good. Similar to SOM, the SR of soil TN under MP (1.1-1.8) was generally lower than NT (1.6-3.2) (Franzluebbers, 2002; Sa and Lal, 2009). In this study, the SR of soil TN in MP and NT treatments was 1.13 and 1.70 on average, respectively (Figure 2), which represented that soil quality in NT was better. Although crop residue was returned to the soil in NT and MP, tillage in MP makes residue evenly distributed in the plough layer and accelerates the mineralization of N (Allmaras et al., 2004; Abreu et al., 2011; Zuber et al., 2015). Rossella et al. (2007) indicated that the effect of tillage practice on soil TN was mainly related to soil texture, climate and cropping system.

Cropping systems with different crop species could change soil microbial dynamics and nutrient supply therefore altering $\mathrm{N}$ cycles (McDaniel et al., 2014; Tian et al., 2015). In our research, cropping system had significant effect on soil TN in all three layers, and the soil TN content in MM was higher than MS under the same tillage practice, NT or MP (Figure 1). The residue quantity (above- and below-ground) of maize is 
about two-fold greater than soybean as annual crops (Prince et al., 2001), thus about 18.6-31.9 $\mathrm{kg} \mathrm{ha}^{-1} \mathrm{yr}^{-1}$ extra $\mathrm{N}$ was returned in MM cropping system (average of maize and soybean phases) (Table 2). In addition to the quantity of crop residue, the different chemical composition of maize and soybean residue resulted in a different turnover rate of crop residue which was also a major factor affecting soil TN. Blanco-Canqui and Lal (2004) found soybean residue decomposed faster for its lower C:N ratio, and maize residue usually decomposed over a longer period (Abail and Whalen, 2018; Dou et al., 2018). Recently, Zheng et al., (2021) demonstrated that slowly decomposing residues favor soil $\mathrm{N}$ store in relative to more rapidly decomposing residues. These results are consistent with the results of this study.

The $\mathrm{N}$ storage in croplands is strongly influenced by agricultural management such as tillage practice, cropping systems and residue management. The soil N storage in residue return treatments was $6.44 \%$ $24.85 \%$ higher compared with CTMM in plough layer $(0-20 \mathrm{~cm}$ ) (Table 2), which highlighted the importance of crop residue retention to soil $\mathrm{N}$ storage. Some studies also indicated that the positive effects of residue return on soil $\mathrm{N}$ storage mainly occurred in 0-20 cm layer, but a generally equal or substantial reduction in deeper layer under NT (Dolan et al., 2006; Gal et al., 2007). In our study, the stratification of soil TN was observed under NT in plough layer, but the $\mathrm{N}$ storage indeed increased which was related to the annual $\mathrm{N}$ input of residue (Figure 3). In comparison with CTMM, the [?] N storage of NTMM was the highest for $887.03 \mathrm{~kg} \mathrm{~N} \mathrm{ha}^{-1}$ (Table 2), equivalent to increase soil $\mathrm{N}$ storage by $59 \mathrm{~kg} \mathrm{~N} \mathrm{ha} \mathrm{yr}^{-1}$ on average. This was higher than the average increment of $\mathrm{N}$ storage with $28 \mathrm{~kg} \mathrm{~N} \mathrm{ha}^{-1} \mathrm{yr}^{-1}$ under NT reported by Franzluebbers (2004), but less than the accumulation rates of $\mathrm{N}$ storage with $100 \mathrm{~kg} \mathrm{~N} \mathrm{ha}^{-1} \mathrm{yr}^{-1}$ under NT in subtropical region in 0-30 cm (Bayer et al., 2000). The ability of $\mathrm{N}$ fixation under residue return was differ in diverse regions, soil depth and cultivation years. Overall, the positive impact of NTMM on soil N storage can be explained from two main aspects, first is the increase of $\mathrm{N}$ derive from crop residue (Mazzoncini et al., 2011; Dolan et al., 2006), and second is the decrease of N loss due to less soil disturbance (Sainju et al., 2009).

4.2 Effect of tillage practice and cropping system on the change of $N$ storage in physical fractions under residue return

The traditional CTMM was practiced for more than 15 years on the field site prior to initiation of the long-term experiment, and consequently, the soil status was assumed to be the same for all treatments when the experiment was established in 2001. The gain/loss of soil $\mathrm{N}$ storage in residue return treatments were calculated based on CTMM, and are thus relative to any changes in CTMM.

After returning crop residues, the distribution of LF- and sand-[?]N storage were mainly influenced by tillage practice (Figure 5, e-f), the increase of LF- and sand-[?]N storage $(0-20 \mathrm{~cm})$ in NT treatments was significantly higher than MP treatments under the same cropping system (Figure 4a, 4b). This indicated that there was more undecomposed and semi-decomposed residue under NT, which was regarded as a potential active $\mathrm{N}$ pool (Coppens et al., 2010). Ramnarine et al., (2015) also found that LF-N storage $(0-10 \mathrm{~cm})$ was higher under NT in a silt loam in southern Ontario, Canada, the similar trend was observed in Ohio, USA by Tan et al., (2007). As newly incorporated and partially decomposed plant debris of soil, LF is the most sensitive fraction to agricultural management (Whalen et al., 2000; Ramnarine et al., 2015). LF together with sand-size fraction was often considered as particulate organic matter (POM) which was derived from plant residues (Jafarzadeh-Haghighi et al., 2016). Tillage practice under MP, like ploughing, can disrupt soil aggregate structure and release physically protected N (Fernandez-Ugalde et al., 2009), thereby accelerating the decomposition of relatively labile $\mathrm{N}$ pool. Thus, only $19.27 \%$ and $8.24 \%$ of the [?]N storage was accumulated in LF and sand size fractions under MPMM and MPMS, respectively. While LFand sand-[?]N storage accounted for $31.29 \%$ (NTMM) and $39.12 \%$ (NTMS) of the [?]N storage in this study (Figure 4b). Oorts et al. (2007) found that PON (particulate organic nitrogen, equivalent to the LF-N + sand-N) contributed about $50 \%$ to the variance of $\mathrm{N}$ storage after 32 years of NT. It can be inferred that the accumulation of these relatively labile $\mathrm{N}$ pools in response to residue return need time.

It was found that the distribution of silt- and clay-[?]N storage was mainly influenced by cropping system under residue return (Figure 5, g-h). The decomposability of crop residues was different owing to its substrate quality, and it was also determined by the activity of microbial (Cordova et al., 2018; Zuber et al., 2015). 
More and more evidences indicate that SOM associated with silt- and clay-size fractions was primarily derived from microbial metabolism (Christensen, 2001; Cyle et al., 2016). Therefore, it has been generally considered that the silt- $\mathrm{N}$ and clay- $\mathrm{N}$ was relatively stable due to the physiochemical interactions (Six et al., 2002; Bol et al., 2009;), and the increase of $\mathrm{N}$ storage in silt size and clay size could enhance the stability of soil $\mathrm{N}$ pools. Of all physical fractions, the proportion of [?]N storage in clay size was the biggest under MS treatments (Figure 4b), however, the decrease of silt-[?]N storage was also observed (Figure 4a). This suggested that most of the $\mathrm{N}$ derived from crop residue under maize-soybean rotation was associated with clay size fraction, and this process was proved to be dominated by fungi activity (Helfrich et al., 2008; Soares and Rousk, 2019). Nevertheless, the maize-soybean rotation might stimulate the microbial to decompose the $\mathrm{N}$ associated with silt size in soil, increasing the risk of $\mathrm{N}$ loss.

\section{Conclusion}

Soil total nitrogen $(\mathrm{TN})$ content showed significantly stratified in NT treatments than MP treatments. Cropping system affected the soil TN content with MM > MS. Relative to the CTMM, the highest and lowest [?]N storage was observed in NTMM and MPMS under residue return, respectively. Of all physical fractions, clay account for the most for the [?]N storage under residue return. Continuous maize (MM) enhanced N storage in all physical fractions, whereas the decline of silt-N storage was found under maize-soybean rotation (MS), this suggests that maize-soybean rotation affects the stability of $\mathrm{N}$ pools. The distribution of [?] $\mathrm{N}$ storage in LF and sand size fractions was influenced by tillage practice, whereas the distribution of [?]N storage in silt size and clay size fractions was influenced by cropping system. In summary, soil $\mathrm{N}$ storage in NTMM was the highest, and N storage in all physical fractions was enhanced. This indicates that NTMM is beneficial to plant growth, soil $\mathrm{N}$ storage accumulation and the stability of $\mathrm{N}$ pools from the perspective of physical $\mathrm{N}$ pools.

Acknowledgements

This research was supported by Science and Technology Project for Black Soil Granary (XDA28080200), Strategic Priority Research Program of the Chinese Academy of Sciences (XDA2307050103), National Natural Science Foundation of China (41877095 and 42101277), Innovation Leadership and Team Program in Sciences and Technologies for Young and Middle-aged Scientists of Jilin Province (20200301022RQ) and Open Project of CAS Key Laboratory of Mollisols Agroecology (2020ZKHT-06). The authors would like to thank Siyi Liu for his valuable comments and suggestions on the manuscript.

\section{References}

Abail, Z., Whalen, J.K., 2018. Corn residue inputs influence earthworm population dynamics in a no-till corn-soybean rotation. Appl. Soil Ecol. 127, 120-128.

Abreu, S.L., Godsey, C.B., Edwards, J.T., Warren, J.G., 2011. Assessing carbon and nitrogen stocks of no-till systems in Oklahoma. Soil Till. Res. 117, 28-33.

Allmaras, R.R., Linden, D.R., Clapp, C.E., 2004. Corn-residue transformations into root and soil carbon as related to nitrogen, tillage, and stover management. Soil Sci. Soc. Am. J. 68, 1366-1375.

Angers, D.A., Bolinder, M.A., Carter, M.R., Gregorich, E.G., Drury, C.F., Liang, B.C., Voroney, R.P., Simard, R.R., Donald, R.G., Beyaert, R.P., Martel, J., 1997. Impact of tillage practices on organic carbon and nitrogen storage in cool, humid soils of eastern Canada. Soil Till. Res. 41, 191-201.

Bailey, K.L., Lazarovits, G., 2003. Suppressing soil-borne diseases with residue management and organic amendments. Soil Till. Res. 72, 169-180.

Bayer, C., Mielniczuk, J., Amado, T., Martin-Neto, L., Fernandes, S.V., 2000. Organic matter storage in a sandy clay loam Acrisol affected by tillage and cropping systems in southern Brazil. Soil Till. Res. 54, 101-109. 
Blanco-Canqui, H., Lal, R., 2004. Mechanisms of carbon sequestration in soil aggregates. Crit. Rev. Plant Sci. 23, 481-504.

Bol, R., Poirier, N., Balesdent, J., Gleixner, G., 2009. Molecular turnover time of soil organic matter in particle-size fractions of an arable soil. Rapid Commun. Mass Spectrom. 23, 2551-2558.

Bowles, T.M., Atallah, S.S., Campbell, E.E., Gaudin, A.C.M., Wieder, W.R., Grandy, A.S., 2018. Addressing agricultural nitrogen losses in a changing climate. Nat. Sustain. 1, 399-408.

Cassman, K.G., Dobermann, A., Walters, D.T., 2002. Agroecosystems, nitrogen-use efficiency, and nitrogen management. Ambio 31, 132-140.

Chen, H.Q., Hou, R.X., Gong, Y.S., Li, H.W., Fan, M.S., Kuzyakov, Y., 2009. Effects of 11 years of conservation tillage on soil organic matter fractions in wheat monoculture in loess plateau of China. Soil Till. Res. 106, 85-94.

Christensen, B.T., 2001. Physical fractionation of soil and structural and functional complexity in organic matter turnover. Eur. J. Soil Sci. 52, 345-353.

Congreves, K.A., Hooker, D.C., Hayes, A., Verhallen, E.A., Eerd, L.L.V., 2016. Interaction of long-term nitrogen fertilizer application, crop rotation, and tillage system on soil carbon and nitrogen dynamics. Plant and Soil 410, 113-127.

Coppens, F., Garnier, P., Gryze, S.D., Merckx, R., Recous, S., 2010. Soil moisture, carbon and nitrogen dynamics following incorporation and surface application of labelled crop residues in soil columns. Eur. J. Soil Sci. 57, 894-905.

Cordova, S.C., Olk, D.C., Dietzel, R.N., Mueller, K.E., Archontouilis, S.V., Castellano, M.J., 2018. Plant litter quality affects the accumulation rate, composition, and stability of mineral-associated soil organic matter. Soil Biol. Biochem. 125, 115-124.

Cyle, K.T., Hill, N., Young, K., Jenkins, T., Hancock, D., Schroeder, P.A., Thompson, A., 2016. Substrate quality influences organic matter accumulation in the soil silt and clay fraction. Soil Biol. Biochem. 103, $138-148$.

Diochon, A., Gillespie, A.W., Ellert, B.H., Janzen, H.H., Gregorich, E.G., 2016. Recovery and dynamics of decomposing plant residue in soil: an evaluation of three fractionation methods. Eur. J. Soil Sci. 67, 196-205.

Dolan, M.S., Clapp, C.E., Allmaras, R.R., Baker, J.M., Molina, J.A.E., 2006. Soil organic carbon and nitrogen in a Minnesota soil as related to tillage, residue and nitrogen management. Soil Till. Res. 89, $221-231$.

Dou, X., Li, F., Cheng, X., Zhu, P., 2018. Soil organic carbon and nitrogen dynamics induced by continuous maize cropping compared to maize-soya bean rotation. Eur. J. Soil Sci. 69, 535-544.

Ellert, B.H., Bettany, J.R., 1995. Calculation of organic matter and nutrients stored in soils under contrasting management regimes. Can. J. Soil Sci. 75, 529-538.

Fernandez-Ugalde, O., Virto, I., Bescansa, P., Imaz, M.J., Enrique, A., Karlen, D.L., $2009 . \quad$ No-tillage improvement of soil physical quality in calcareous, degradation-prone, semiarid soils. Soil Till. Res. 106, 29-35.

Fowler, D., Pyle, J.A., Raven, J.A., Sutton, M.A., 2013. The global nitrogen cycle in the twenty-first century: introduction. Philos. Trans. R. Soc. B Biol Sci. 368.

Franzluebbers, A.J., 2002. Soil organic matter stratification ratio as an indicator of soil quality. Soil Till. Res. 66, 95-106. 
Franzluebbers, A.J., 2004. Tillage and residue management effects on soil organic matter. In: Magdoff, F., Weil, R.R. (Eds.), Soil Organic Matter in Sustainable Agriculture. CRC Press, Boca Raton, FL, USA pp. $227-268$.

Gal, A., Vyn, T.J., Micheli, E., Kladivko, E.J., McFee, W.W., 2007. Soil carbon and nitrogen accumulation with long-term no-till versus moldboard plowing overestimated with tilled-zone sampling depths. Soil Till. Res. 96, 42-51.

Galloway, J.N., 2003. The global nitrogen cycle. Biogeochemistry 8, 557-583.

Helfrich, M., Ludwig, B., Potthoff, M., Flessa, H., 2008. Effect of litter quality and soil fungi on macroaggregate dynamics and associated partitioning of litter carbon and nitrogen. Soil Biol. Biochem. 40, 1823-1835.

Jafarzadeh-Haghighi, A.H., Shamshuddin, J., Hamdan, J., Zainuddin, N., 2016. Structural composition of organic matter in particle-size fractions of soils along a climo-biosequence in the main range of Peninsular Malaysia. Open Geosci. 8, 503-513.

Jagadamma, S., Lal, R., Hoeft, R.G., Nafziger, E.D., Adee, E.A., 2007. Nitrogen fertilization and cropping systems effects on soil organic carbon and total nitrogen pools under chisel-plow tillage in Illinois. Soil Till. Res. 95, 348-356.

Kroetsch, D., Wang, C., 2006. Particle size distribution. In: Carter, M.R., Gregorich, E.G., (Eds.), Soil Sampling and Methods of Analysis. CRC Press, Boca Raton, FL, USA, pp. 713-726.

Liang, A.Z., Zhang, X.P., Fang, H.J., Yang, X.M., Drury, C.F., 2007. Short-term effects of tillage practices on organic carbon in clay loam soil of Northeast China. Pedosphere 17, 619-623.

Magid, J., Kjaergaard, C., 2001. Recovering decomposing plant residues from the particulate soil organic matter fraction: size versus density separation. Biol. Fert. Soils 33, 252-257.

Mazzoncini, M., Sapkota, T.B., Barberi, P., Antichi, D., Risaliti, R., 2011. Long-term effect of tillage, nitrogen fertilization and cover crops on soil organic carbon and total nitrogen content. Soil Till. Res. 114, $165-174$.

McDaniel, M.D., Grandy, A.S., Tiemann, L.K. Weintraub, M.N., 2014. Crop rotation complexity regulates the decomposition of high and low quality residues. Soil Biol. Biochem. 78, 243-254.

Oorts, K., Bossuyt, H., Labreuche, J., Merckx, R., Nicolardot, B., 2007. Carbon and nitrogen stocks in relation to organic matter fractions, aggregation and pore size distribution in no-tillage and conventional tillage in northern France. Eur. J. Soil Sci. 58, 248-259.

Prince, S.D., Haskett, J., Steininger, M., Strand, H., Wright, R., 2001. Net primary production of US midwest croplands from agricultural harvest yield data. Ecol. Appl. 11, 1194-1205.

Ramnarine, R., Voroney, R.P., Wagner-Riddle, C., Dunfield, K.E., 2015. Conventional and no-tillage effects on the distribution of crop residues and light fraction organic matter. Soil Sci. Soc. Am. J. 79, 74-80.

Rossella, P., Giuseppe, V., Carlo, P., Giorgio, B., 2007. Nitrogen and phosphorous in a loam soil of central Italy as affected by 6 years of different tillage systems. Soil Till. Res. 92, 175-180.

Sa, J.C.M., Lal, R., 2009. Stratification ratio of soil organic matter pools as an indicator of carbon sequestration in a tillage chronosequence on a Brazilian Oxisol. Soil Till. Res. 103, 46-56.

Sainju, U.M., Caesar-Tonthat, T., Lenssen, A.W., Evans, R.G., Kolberg, R., 2009. Tillage and cropping sequence impacts on nitrogen cycling in dryland farming in eastern Montana, USA. Soil Till. Res. 103, $332-341$.

Six, J., Conant, R.T., Paul, E.A., Paustian, K., 2002. Stabilization mechanisms of soil organic matter: implications for C-saturation of soils. Plant and Soil 241, 155-176. 
Soares, M., Rousk, J., 2019. Microbial growth and carbon use efficiency in soil: links to fungal-bacterial dominance, SOC-quality and stoichiometry. Soil Biol. Biochem. 131, 195-205.

Spargo, J.T., Alley, M.M., Follett, R.F., Wallace, J.V., 2008. Soil nitrogen conservation with continuous no-till management. Nutr. Cycl. Agroecosys. 82, 283-297.

Tan, Z., Lal, R., Owens, L., Izaurralde, R.C., 2007. Distribution of light and heavy fractions of soil organic carbon as related to land use and tillage practice. Soil Till. Res. 9, 53-59.

Tian, K., Zhao, Y.C., Xu, X.H., Hai, N., Huang, B., Deng, W.J., 2015. Effects of long-term fertilization and residue management on soil organic carbon changes in paddy soils of China: a meta-analysis. Agr. Ecosyst. Environ. 204, 40-50.

Varvel, G.E., Wilhelm, W.W., 2011. No-tillage increases soil profile carbon and nitrogen under long-term rainfed cropping systems. Soil Till. Res. 114, 28-36.

Vitousek, P.M., Naylor, R., Crews, T., David, M.B., Drinkwater, L.E., Holland, E., Johnes, P.J., Katzenberger, J., Martinelli, L.A., Matson, P.A., 2009. Nutrient imbalances in agricultural development. Science $324,1519-1520$.

Wang, M., Pendall, E., Fang, C.M., Li, B., Nie, M., 2018. A global perspective on agroecosystem nitrogen cycles after returning crop residue. Agr. Ecosyst. Environ. 266, 49-54.

Wang, X.J., Jia, Z.K., Liang, L.Y., 2015. Effect of straw incorporation on the temporal variations of water characteristics, water-use efficiency and maize biomass production in semi-arid China. Soil Till. Res. 153, $36-41$.

Whalen, J.K., Bottomley, P.J., Myrold, D.D., 2000. Carbon and nitrogen mineralization from light- and heavy-fraction additions to soil. Soil Biol. Biochem. 32, 1345-1352.

Zhang, L., Liu, H.H., Sun, J.Q., Li, J.C., Song, Y., 2018. Seedling characteristics and grain yield of maize grown under straw retention affected by sowing irrigation and splitting nitrogen use. Field Crops Res. 225, $22-31$.

Zhang, Y., Li, X.J., Gregorich E.G., McLaughlin, N.B., Zhang, X.P., Guo, Y.F., Gao, Y., Liang, A.Z., 2019. Evaluating storage and pool size of soil organic carbon in degraded soils: Tillage effects when crop residue is returned. Soil Till. Res. 192, 215-221.

Zheng, Y., Hu, Z.K., Pan, X., Chen, X.Y., Derrien, D., Hu, F., Liu, M.Q., Hattenschwiler, S., 2021. Carbon and nitrogen transfer from litter to soil is higher in slow than rapid decomposing plant litter: a synthesis of stable isotope studies. Soil Biol. Biochem. 156, 108196.

Zuber, S.M., Behnke, G.D., Nafziger, E.D., Villamil, M.B., 2015. Crop rotation and tillage effects on soil physical and chemical properties in Illinois. Agron. J. 107, 971-978.

\section{Hosted file}

Tables.docx available at https://authorea.com/users/453661/articles/551438-nitrogen-storagein-density-and-size-fractions-varied-with-tillage-practices-and-cropping-systems-underresidue-return 

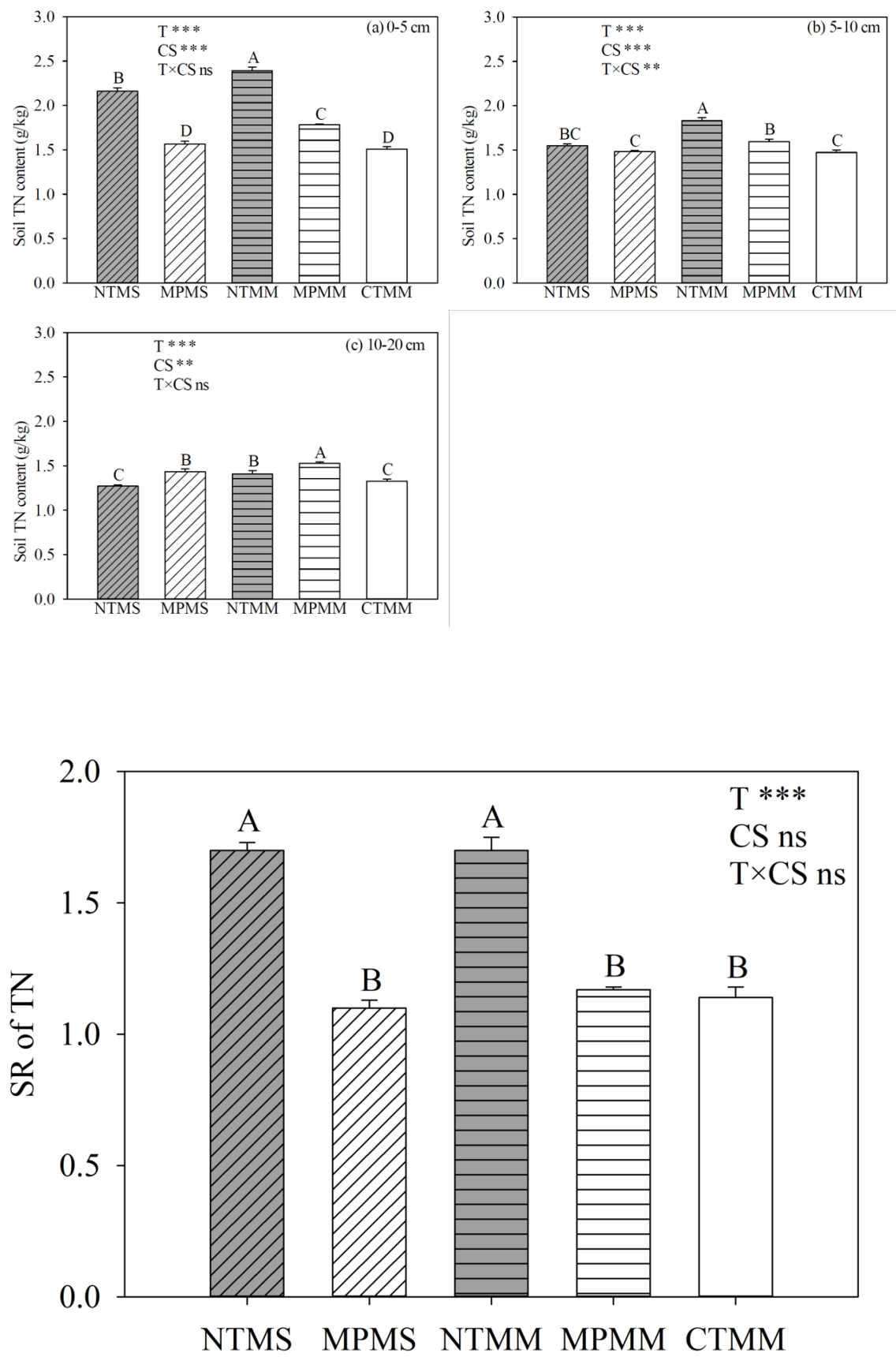

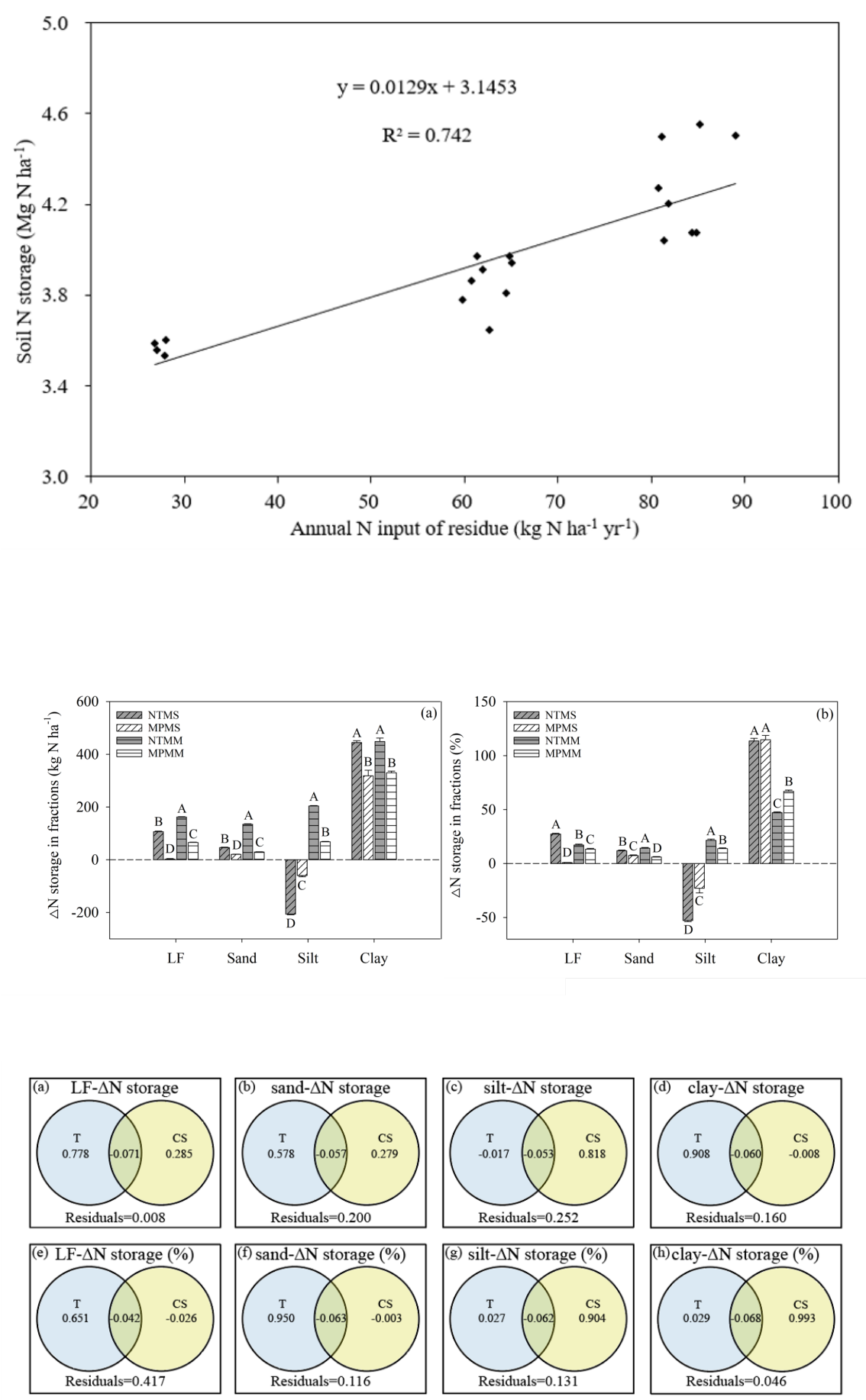